\title{
Role of ammonia in forming secondary aerosols from gasoline vehicle exhaust
}

\author{
Tengyu Liu ${ }^{1,2}$, Xinming Wang ${ }^{1 *}$, Wei Deng ${ }^{1,2}$, Yanli Zhang ${ }^{1}$, Biwu Chu ${ }^{3}$, Xiang Ding ${ }^{1}$, \\ Qihou $\mathrm{Hu}^{1}$, Hong $\mathrm{He}^{3} \&$ Jiming $\mathrm{Hao}^{4}$ \\ ${ }^{1}$ State Key Laboratory of Organic Geochemistry, Guangzhou Institute of Geochemistry, Chinese Academy of Sciences, \\ Guangzhou 510640, China \\ ${ }^{2}$ University of Chinese Academy of Sciences, Beijing 100049, China \\ ${ }^{3}$ Research Center for Eco-Environmental Sciences, Chinese Academy of Sciences, Beijing 100085, China \\ ${ }^{4}$ State Key Joint Laboratory of Environment Simulation and Pollution Control, School of Environment, Tsinghua University, \\ Beijing 100084, China
}

Received January 25, 2015; accepted February 12, 2015; published online May 6, 2015

\begin{abstract}
Ammonia $\left(\mathrm{NH}_{3}\right)$ plays vital roles in new particle formation and atmospheric chemistry. Although previous studies have revealed that it also influences the formation of secondary organic aerosols (SOA) from ozonolysis of biogenic and anthropogenic volatile organic compounds (VOCs), the influence of $\mathrm{NH}_{3}$ on particle formation from complex mixtures such as vehicle exhausts is still poorly understood. Here we directly introduced gasoline vehicles exhausts (GVE) into a smog chamber with $\mathrm{NH}_{3}$ absorbed by denuders to examine the role of $\mathrm{NH}_{3}$ in particle formation from GVE. We found that removing $\mathrm{NH}_{3}$ from GVE would greatly suppress the formation and growth of particles. Adding $\mathrm{NH}_{3}$ into the reactor after 3 h photo-oxidation of GVE, the particle number concentration and mass concentrations jumped explosively to much higher levels, indicating that the numbers and mass of particles might be enhanced when aged vehicle exhausts are transported to rural areas and mixed with $\mathrm{NH}_{3}$-rich plumes. We also found that the presence of $\mathrm{NH}_{3}$ had no significant influence on SOA formation from GVE. Very similar oxygen to carbon (O:C) and hydrogen to carbon $(\mathrm{H}: \mathrm{C})$ ratios resolved by aerosol mass spectrometer with and without $\mathrm{NH}_{3}$ indicated that the presence of $\mathrm{NH}_{3}$ also had no impact on the average carbon oxidation state of SOA from GVE.
\end{abstract}

ammonia, vehicle exhaust, secondary organic aerosols (SOA), smog chamber, fine particles, nitrogen oxides, volatile organic compounds

\section{Introduction}

Ammonia $\left(\mathrm{NH}_{3}\right)$, a ubiquitous gas, is the third abundant nitrogen-containing gas in the atmosphere [1]. Atmospheric $\mathrm{NH}_{3}$ is mainly emitted from animal waste, biological processes in soils and ammonia-based chemical fertilizers, followed by biomass burning, and sewage treatment plants $[2,3]$. The gas-phase reactions between $\mathrm{NH}_{3}$ and inorganic acids such as nitric and sulfuric acid can form ammonium

*Corresponding author (email: wangxm@gig.ac.cn) nitrate and sulfate [4], which are important constituents of airborne fine particles or $\mathrm{PM}_{2.5}$ [5]. In China's megacities, which are frequently hard-hit by severe haze due to $\mathrm{PM}_{2.5}$ pollution in the recent decade [6,7], ammonium alone has contributed more than $5 \%$ of the $\mathrm{PM}_{2.5}$ mass [8-12].

$\mathrm{NH}_{3}$ can enhance the nucleation of sulfuric acid particles and thus influence new particle formation events [13,14]. In addition, recent smog chamber simulations indicate that $\mathrm{NH}_{3}$ can enhance the secondary organic aerosol (SOA) formation from ozonolysis of biogenic precursors by reacting with organic acids $[15,16]$, but reduce SOA formation from the styrene-ozone system [17]. However, the potential 
influence of $\mathrm{NH}_{3}$ on SOA formation is still poorly understood, especially for complex chemical mixtures such as vehicle exhausts brimming with thousands of gaseous and particle-phase components [18]. SOA, which is ubiquitous in various atmospheric environments, respectively accounts for approximately $66 \%$ and $90 \%$ of the total OA in urban as well as urban downwind and rural sites in Northern Hemisphere mid-latitudes [19]. Current chemical transport models usually underestimate the level of OA mainly due to the unclear formation processes and sources of SOA [20]. A detailed investigation of the potential influence of $\mathrm{NH}_{3}$ on SOA formation from vehicle exhaust is therefore necessary to better understand the formation pathways and sources of SOA.

In urban areas with high population densities, $\mathrm{NH}_{3}$ is centralized and significantly emitted from sewage. Recent tunnel studies indicated that emissions from light-duty gasoline vehicles (LDGVs) are also an important source of $\mathrm{NH}_{3}$ [21-25]. Nordin et al. [26] found that SOA formed from the exhaust of idling gasoline vehicles could be 1-2 orders of magnitude higher than POA. Gordon et al. [18] and Platt et al. [27] also observed an enhancement of SOA/POA from 1 to 15 during the aging of emissions from LDGVs. Significant nitrate and ammonium were observed to be formed synchronously with SOA during the photooxidation of LDGV exhaust $[18,26]$. However, the formation of secondary aerosols including SOA, nitrate, and ammonium from vehicle exhaust still remain uncertain when $\mathrm{NH}_{3}$ is removed. Therefore, studying the role of $\mathrm{NH}_{3}$ in forming secondary aerosols from vehicle exhaust might give a better understanding of the tropospheric chemistry in urban areas, as well as the aging of vehicle exhausts transported into $\mathrm{NH}_{3}$-rich plumes emitted from livestock waste and fertilizers in rural areas.

Here we introduce exhaust from LDGVs directly into a smog chamber with a $30 \mathrm{~m}^{3}$ Teflon reactor with $\mathrm{NH}_{3}$ absorbed by denuders, to study the role of $\mathrm{NH}_{3}$ in particle formation under photo-oxidation. The purpose is to understand the effects of $\mathrm{NH}_{3}$ on secondary aerosol formation from LDGV exhaust, and to obtain valuable information for the future emission control of $\mathrm{NH}_{3}$ and vehicle exhaust.

\section{Methods}

\subsection{Vehicles and fuel}

Two port fuel injected Euro 1 and Euro 4 LDGVs with model years of 2002 and 2011 were used in this study. More details of each vehicle are listed in Table 1 . They were fueled with Grade 93\# gasoline, which complies with the Euro III gasoline fuel standard. The gasoline compositions were described in our previous study [28].
Table 1 Detailed information on the two light-duty gasoline vehicles

\begin{tabular}{cccccccc}
\hline ID & $\begin{array}{c}\text { Emission } \\
\text { standard } \\
\text { class }\end{array}$ & Vehicle & $\begin{array}{c}\text { Model } \\
\text { year }\end{array}$ & $\begin{array}{c}\text { Mileage } \\
(\mathrm{km})\end{array}$ & $\begin{array}{c}\text { Displacement } \\
\left(\mathrm{cm}^{3}\right)\end{array}$ & $\begin{array}{c}\text { Power } \\
(\mathrm{kW})\end{array}$ & $\begin{array}{c}\text { Weight } \\
(\mathrm{kg})\end{array}$ \\
\hline I & Euro4 & Golf & 2011 & 25000 & 1598 & 77 & 1295 \\
II & Euro1 & Accord & 2002 & 237984 & 2298 & 110 & 1423 \\
\hline
\end{tabular}

\subsection{Smog chamber experiments}

Six photochemical experiments were conducted in the smog chamber in Guangzhou Institute of Geochemistry, Chinese Academy of Sciences (GIG-CAS). The GIG-CAS smog chamber has a $30 \mathrm{~m}^{3}$ fluorinated ethylene propylene (FEP) reactor housed in a temperature-controlled room. Details of setup and facilities about the chamber are described elsewhere [29]. Prior to each experiment, the chamber was evacuated and filled with purified dry air at least 5 times, after which the reactor was flushed with purified dry air for at least $48 \mathrm{~h}$ until no residual hydrocarbons, $\mathrm{O}_{3}, \mathrm{NO}_{x}$, or particles were detected. In the present study, temperature and $\mathrm{RH}$ inside the reactor were respectively set to $25^{\circ} \mathrm{C}$ and $50 \%$.

Before the introduction of vehicle exhaust, the test vehicle was at idling for at least $30 \mathrm{~min}$ to warm up the threeway catalysts. Next, vehicle exhaust was directly introduced into the reactor by two oil-free pumps (Gast Manufacturing, Inc, USA). For comparison, ammonia in LDGV exhaust from experiments I-2, II-2, and II-3 (Table 2) was absorbed by denuders coated with a solution of phosphorous acid in 1:9 water and ethanol [30].

After the introduction of exhaust, additional NO was added to adjust the $\mathrm{VOC} / \mathrm{NO}_{x}$ ratios to $2.0-5.0$ (Table 2), which was within the range of $0.5-10$ in gasoline vehicle exhaust and downwind urban areas [31]. There were experiment-to-experiment differences in initial precursor concentrations due to the technical challenges of introducing the same amounts of exhaust into the reactor. We kept similar non methane hydrocarbons (NMHCs) concentrations for comparison experiments such as I-1 and I-2. After more than $30 \mathrm{~min}$ of primary characterization, the exhaust was continuously exposed to black light for $5 \mathrm{~h}$. After the black lamps were switched off, the formed particles were characterized for another $2-3 \mathrm{~h}$ to correct the particle wall loss.

A series of instruments was used to characterize the gasand particle-phase compounds in the reactor. Gas-phase ozone $\left(\mathrm{O}_{3}\right)$ and $\mathrm{NO}_{x}$ were measured online with dedicated monitors (EC9810 and 9841T, Ecotech, Australia). Methane and $\mathrm{CO}$ concentrations were determined using a gas chromatography (Agilent 6980GC, USA) with a flame ionization detector and a packed column (5A Molecular Sieve 60/80 mesh, $3 \mathrm{~m} \times 1 / 8 \mathrm{inch}$ [ [32], and $\mathrm{CO}_{2}$ was analyzed with a gas chromatography (HP 4890D, USA) [33]. Gasphase organic species such as $\mathrm{C}_{6}-\mathrm{C}_{10}$ single-ring aromatic hydrocarbons were measured with a Mode 7100 preconcentrator (Entech Instruments Inc., USA) coupled with an 
Table 2 Summary of the initial conditions and results of the light-duty gasoline vehicle photo-oxidation experiments

\begin{tabular}{|c|c|c|c|c|c|c|c|c|}
\hline $\operatorname{Exp} \#^{\text {a) }}$ & $\begin{array}{c}\mathrm{OH} \\
\left(\times 10^{6} \text { molecules } / \mathrm{cm}^{3}\right)\end{array}$ & $\begin{array}{c}T \\
\left({ }^{\circ} \mathrm{C}\right) \\
\end{array}$ & RH (\%) & $\mathrm{VOC} / \mathrm{NO}_{x}$ & NMHCs (ppbv) & $\begin{array}{c}\mathrm{NO} \\
(\mathrm{ppbv})\end{array}$ & $\mathrm{NO}_{2}$ (ppbv) & $\mathrm{SO}_{2}$ (ppbv) \\
\hline $\mathrm{I}-1$ & 1.20 & 24.2 & 52.5 & 2.0 & 1885 & 794.1 & 161.9 & 7.2 \\
\hline $\mathrm{I}-2^{\mathrm{b})}$ & 1.18 & 24.8 & 54.3 & 3.6 & 1821 & 496.9 & 2.8 & 6.8 \\
\hline II-1 & 0.80 & 24.6 & 55.6 & 3.0 & 5693 & 1833.3 & 45.9 & 14.7 \\
\hline $\mathrm{II}-2^{\mathrm{b})}$ & 0.79 & 24.4 & 54.6 & 3.9 & 4605 & 1117.8 & 63.3 & 15.0 \\
\hline II $-3^{b)}$ & 0.84 & 25.1 & 51.9 & 4.4 & 1352 & 298.1 & 9.7 & 12.1 \\
\hline II-4 c) & 1.59 & 25.3 & 51.1 & 4.3 & 1303 & 296.2 & 4.4 & 13.3 \\
\hline
\end{tabular}

a) Photooxidation experiments for exhausts from vehicles I and II, described in Table 1; b) for experiments I-2, II-2, and II-3, ammonia in LDGV exhaust was absorbed by denuders coated with a solution of phosphorous acid in 1:9 water and ethanol [30]. Around $100 \mathrm{ppb}$ of $\mathrm{NH}_{3}$ was injected after $4 \mathrm{~h}$ (experiment I-2) and $3 \mathrm{~h}$ of irradiation (experiment II-2); c) around $100 \mathrm{ppb}$ of $\mathrm{NH}_{3}$ was injected before UV irradiation.

Agilent 5973N gas chromatography-mass selective detector/ flame ionization detector/electron capture detector (GCMSD/FID/ECD, Agilent Technologies, USA) [28,32,34,35] and a commercial proton-transfer-reaction time-of-flight mass spectrometer (PTR-TOF-MS, Model 2000, Ionicon Analytik $\mathrm{GmbH}$, Austria) [36,37]. In this study, the decay curve of toluene measured by PTR-TOF-MS was used to derive the average hydroxyl radical $(\mathrm{OH})$ concentration during each experiment.

Particle number concentrations and size distributions were measured with a scanning mobility particle sizer (SMPS, TSI Incorporated, USA; classifier model 3080, CPC model 3775). An aerosol density of $1.4 \mathrm{~g} \mathrm{~cm}^{-3}$ was assumed to convert the particle volume concentration into the mass concentration [38]. A high-resolution time-offlight aerosol mass spectrometer (HR-TOF-MS, Aerodyne Research Incorporated, USA) was used to measure the particle chemical compositions and nonrefractory PM mass $[39,40]$. The instrument was operated in the high sensitivity $\mathrm{V}$-mode and high resolution $\mathrm{W}$-mode alternatively every two minutes. The toolkit Squirrel $1.51 \mathrm{H}$ was used to obtain the time series of various mass components (sulfate, nitrate, ammonium, and organics). We used the toolkit Pika $1.1 \mathrm{H}$ to determine the average element ratios of organics, like $\mathrm{H}: \mathrm{C}$, $\mathrm{O}: \mathrm{C}$, and $\mathrm{N}: \mathrm{C}[41,42]$. The contribution of gas-phase $\mathrm{CO}_{2}$ to the $m / z, 44$ signal was corrected using the measured $\mathrm{CO}_{2}$ concentrations. The HR-TOF-MS was calibrated using 300 $\mathrm{nm}$ monodisperse ammonium nitrate particles.

\subsection{Wall loss corrections}

The loss of particles and organic vapors to the reactor walls must be accounted for to accurately quantify the SOA formation. Briefly, the loss of particles onto the walls has been well constrained and is treated as a first-order process [43]. The wall-loss rate constant was determined separately for each experiment by fitting the SMPS and AMS data when no new particles were formed. By applying this rate to the entire experiment, we used the same method as Pathak et al. [44] to correct the wall loss of the particles. In addition, the aerosol mass measured by HR-TOF-AMS was corrected with SMPS data with the same method used by Gordon et al. [18].

\section{Results and discussion}

\subsection{Effects of $\mathrm{NH}_{3}$ on particle formation and growth}

To investigate the role of $\mathrm{NH}_{3}$ in the formation of secondary aerosols from GVE, we conducted two experiments for each vehicle, with and without $\mathrm{NH}_{3}$ absorbed by denuders. The detailed experimental conditions are listed in Table 2. The average concentration of $\mathrm{OH}$ radicals during the $5 \mathrm{~h}$ of irradiation was similar for each vehicle. Figure 1 shows the temporal evolution of gas-phase species, including NO, $\mathrm{NO}_{2}$, and $\mathrm{O}_{3}$, and the particle number concentrations during the photochemical aging experiments of LDGV exhaust with vehicle II. Between -2.1 and $-1.5 \mathrm{~h}$, the vehicle exhaust was introduced into the reactor, leading to a slight increase of the particle numbers before irradiation. In experiment II-2, $\mathrm{NH}_{3}$ in the exhaust was absorbed by denuders. Obviously, in both experiments, $\mathrm{NO}$ was converted to $\mathrm{NO}_{2}$ after the black lights were turned on. As presented in previous studies, a delay between aerosol formation and the start of irradiation is frequently observed in classic photooxidation experiments; specifically, aerosols may not form until the concentration of NO is around zero [45-47]. In the presence of $\mathrm{NH}_{3}$, the number concentration of particles increased from $\sim 1000$ to $\sim 4000 \mathrm{~cm}^{-3}$ when the concentration of NO was still hundreds of ppb (Figure 1(a)); without $\mathrm{NH}_{3}$, no new particles were formed even when the concentration of NO was approximately zero (Figure 1(b)). Ng et al. [48] found that products formed under high NO conditions via $\mathrm{RO}_{2}+\mathrm{NO}$ reactions partition much less readily into the aerosol phase than products formed via $\mathrm{RO}_{2}+\mathrm{HO}_{2}$ reactions under low NO conditions. Wildt et al. [47] observed that high concentration of NO was responsible for the suppression of new particle formation. Accordingly, higher concentration of NO in experiment II-1 than that in experiment II-2 should have suppressed new particle formation. However, new particle formation was observed only in experiment II-1, indicating that the presence of ammonia in LDGV exhaust might play an important role. Kirkby et al. [14] found that the presence of $100 \mathrm{ppt} \mathrm{NH}_{3}$ could increase the nucleation rate of sulfuric acid particles by a factor of 100-1000. According to a recent study by Kulmala et al. [49], $\mathrm{NH}_{3}$ 

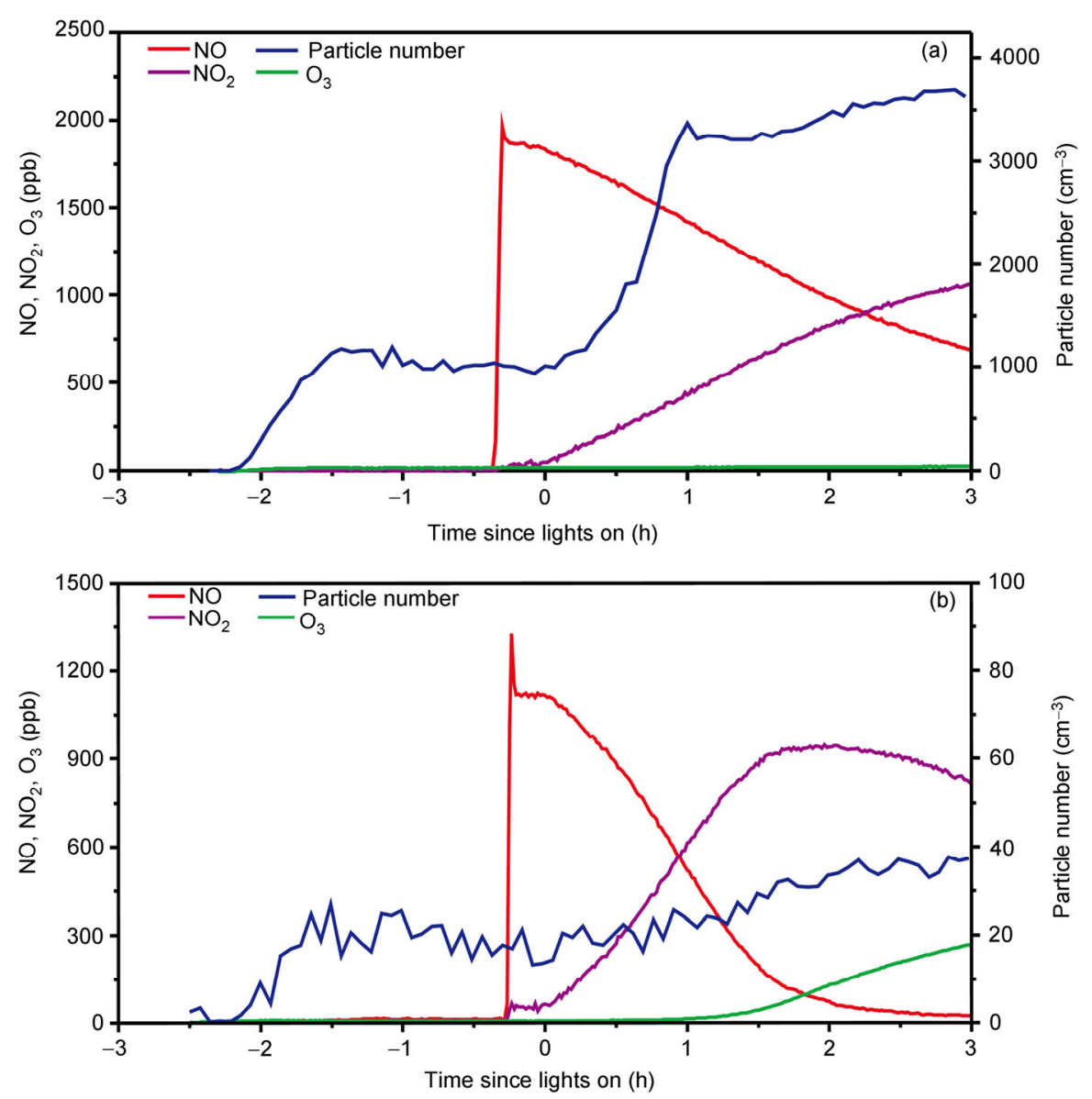

Figure 1 Concentration-time plots of gas-phase species and particle number concentrations in experiments II-1 (a) and II-2 (b) during $3 \mathrm{~h}$ of irradiation. The vehicle exhaust was introduced into the reactor between around -2.1 and $-1.5 \mathrm{~h}$; at time $=0 \mathrm{~h}$, the black lamps were turned on .

can stabilize initial sulfuric acid clusters with diameters of about $1.5 \mathrm{~nm}$. These stable clusters are critical for new particle formation. As shown in Table 2, the initial concentration of $\mathrm{SO}_{2}$ for vehicle II was around $15 \mathrm{ppb} . \mathrm{NH}_{3}$ in GVE might stabilize sulfuric acid formed via the oxidation of $\mathrm{SO}_{2}$ and thus facilitate new particle formation. Consequently, removing $\mathrm{NH}_{3}$ in GVE suppressed new particle formation.

The geometric average diameter increased from 45 to $200 \mathrm{~nm}$ and from 22 to $220 \mathrm{~nm}$ in around $1 \mathrm{~h}$ for experiments I-1 and II-1, with respective particle growth rates of 139 and $181 \mathrm{~nm} \mathrm{~h}^{-1}$; these rates were one order of magnitude higher than those observed in urban environments [50-52]. Some studies have shown that particles larger than $80 \mathrm{~nm}$ can be activated as cloud condensation nuclei (CCN) at moderate atmospheric supersaturation and that they possibly directly and indirectly impact climate $[53,54]$. Therefore, large amounts of LDGV exhaust emissions in urban areas via photochemical aging can influence air quality and even the climate.

As shown in Figure 2, a significant amount of ammonium nitrate was formed through the reaction of $\mathrm{NH}_{3}$ with $\mathrm{HNO}_{3}$ oxidized from NO in experiments I-1 and II-1. The maximum ammonium nitrate production was almost 7 times higher than SOA production, which indicated the significant contribution of LDGV exhaust to secondary inorganic aerosols. Nordin et al. [26] and Gordon et al. [18] also observed significant formation of ammonium nitrate during the aging of gasoline vehicle exhaust in smog chambers; in addition, in-use vehicle emissions mainly from LDGVs in a highway tunnel in Pittsburgh were also found to produce substantial ammonium nitrate [55]. Ammonium has frequently been observed to contribute to particle growth in urban environments [56-58]. Zhu et al. [52] hypothesized that ammonium nitrate plays a role in the particle growth in Qingdao and Toronto during spring. In Figure 3, we plot the concentration of ammonium nitrate without wall loss correction against the geometric average diameter derived from the SMPS data in experiments I-1 and II-1. In both experiments, the geometric average diameter showed significant linear correlations $\left(R^{2}>0.84, P<0.001\right)$ with the concentration of ammonium nitrate, which demonstrated that ammonium nitrate plays an important role in the rapid growth of particles formed from the aging of LDGV exhaust.

A recent study indicated that the $\mathrm{NH}_{3}$ emission factor of LDGVs in China was much higher than those in the United States [23]. However, today's emission standards for LDGV 

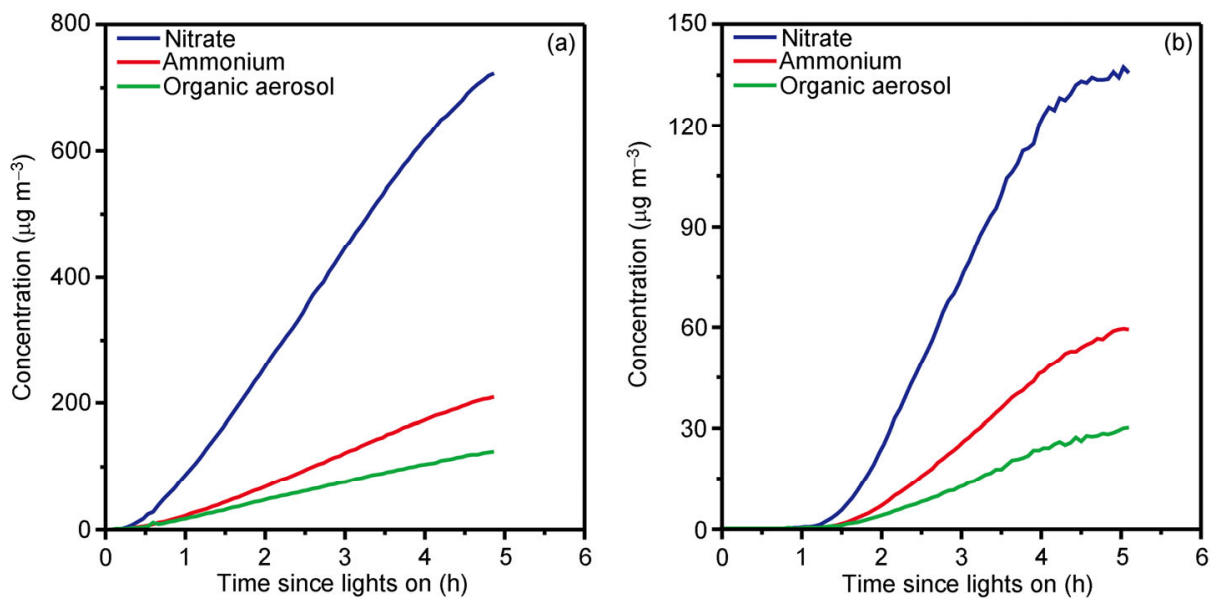

Figure 2 Concentration-time plots of nitrate, ammonium and organic aerosols in experiments. (a) I-1; (b) II-1.
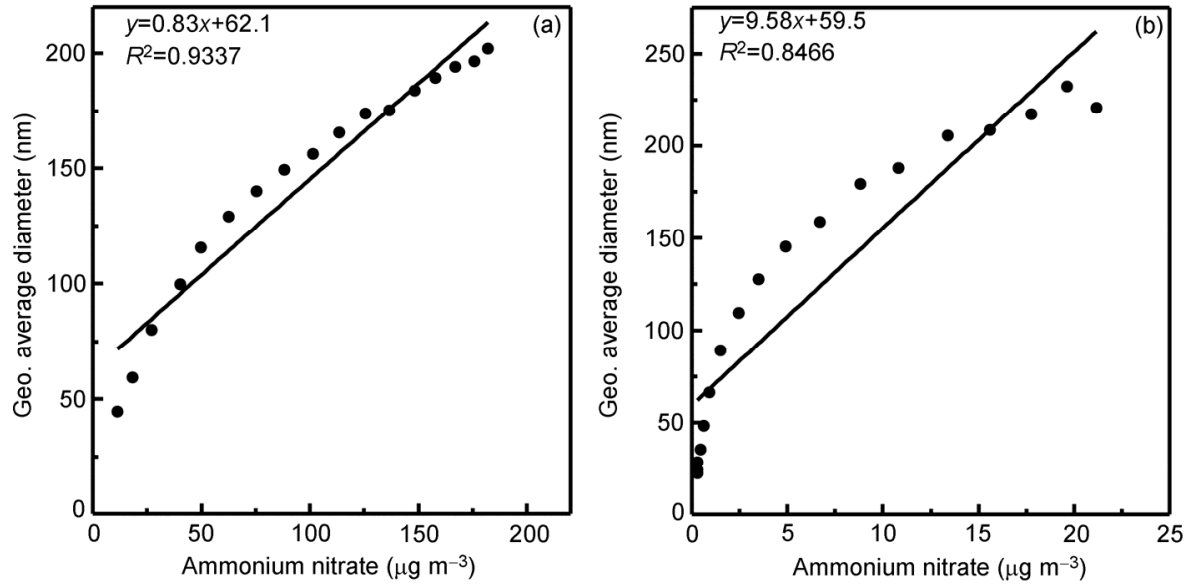

Figure 3 Scatter plots of geometric average diameter against the concentration of ammonium nitrate (without wall loss correction) in experiments I-1 (a) and II-1 (b). Plotted data of the concentration of ammonium nitrate were from around zero to the maximum.

exhaust concern only the primary emissions of hydrocarbon, $\mathrm{NO}_{x}$, and $\mathrm{CO}$. As the presence of $\mathrm{NH}_{3}$ strongly enhances the formation and growth of particles from GVE, removing $\mathrm{NH}_{3}$ from GVE might reduce secondary aerosols formation and benefit air pollution control in urban areas.

\subsection{Effects of $\mathrm{NH}_{3}$ on $\mathrm{SOA}$ formation}

To further investigate the effects of $\mathrm{NH}_{3}$ on SOA formation from LDGV exhaust, we conducted two more experiments, II-3 and II-4, with similar initial concentrations of VOCs and $\mathrm{NO}_{x}$ (Table 2). $\mathrm{NH}_{3}$ in LDGV exhaust in experiment II-3 was absorbed by denuders, whereas in experiment II-4 around $100 \mathrm{ppb}$ of $\mathrm{NH}_{3}$ was injected before the UV lights were turned on. Variations of the geometric average diameters and concentrations of organic aerosols during the irradiation of LDGV exhaust with and without $\mathrm{NH}_{3}$ are shown in Figure 4. With and without adding $\mathrm{NH}_{3}$, the geometric average diameter respectively increased from around $20 \mathrm{~nm}$ to a maximum of 130 and $115 \mathrm{~nm}$ (Figure 4(a)). This result further demonstrates that the presence of $\mathrm{NH}_{3}$ can enhance the growth of particles formed from the aging of LDGV exhaust. As shown in Figure 4(b), in the presence of $\mathrm{NH}_{3}$, SOA was formed more slowly and its concentration was relatively lower. Because the average concentration of $\mathrm{OH}$ radicals during the whole experiment in the presence of $\mathrm{NH}_{3}$ was higher, according to the gas-particle partitioning model [59], SOA formation under a higher $\mathrm{OH}$ concentration and similar concentrations of SOA precursors should be higher. $\mathrm{Na}$ et al. [15] observed that $\mathrm{NH}_{3}$ could neutralize organic acids to enhance SOA formation from $\alpha$-pinene ozonolysis. A recent study [60] demonstrated that $\mathrm{NH}_{3}$ could react with carbonyl groups in SOA molecules to form nitrate-containing compounds. However, in our study the relatively lower concentration of SOA in the presence of $\mathrm{NH}_{3}$ suggested that $\mathrm{NH}_{3}$ might have no significant influences on SOA formation from LDGV exhausts.

The average oxygen to carbon $(\mathrm{O}: \mathrm{C})$ and hydrogen to carbon (H:C) molar ratios of SOA in experiments II-3 and II-4 are presented in Table 3. The O:C and $\mathrm{H}: \mathrm{C}$ ratios in the 

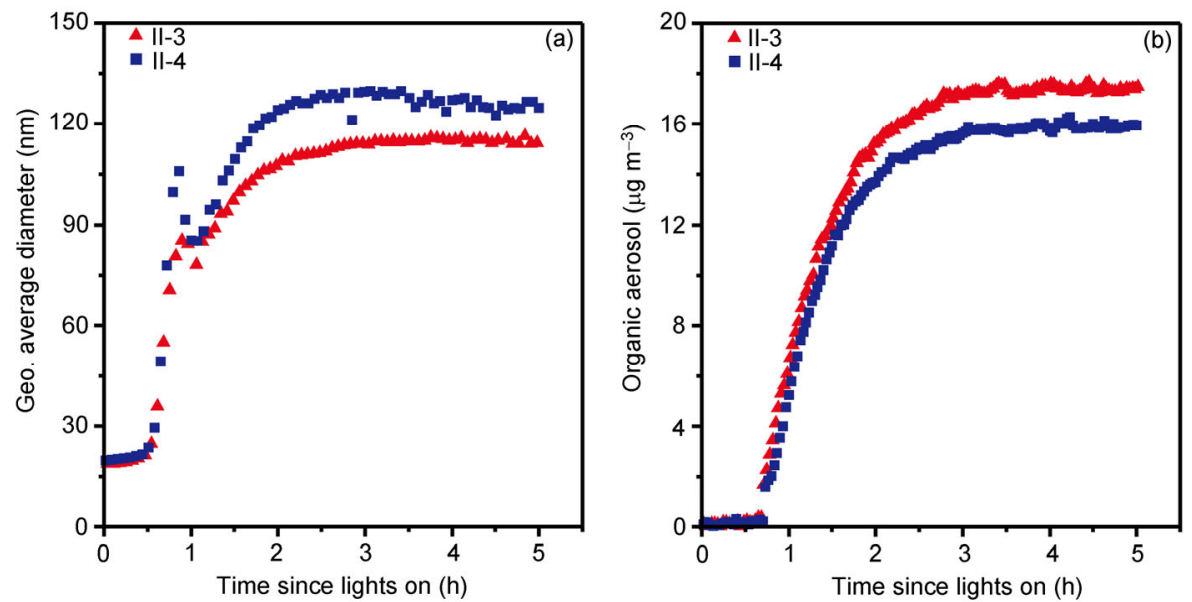

Figure 4 Geometric average diameter (a) and concentration of organic aerosols (b) in experiments II-3 (without $\mathrm{NH}_{3}$ ) and II-4 (with $\left.\mathrm{NH}_{3}\right)$.

presence of $\mathrm{NH}_{3}$ were $0.683 \pm 0.042$ and $1.352 \pm 0.042$, respectively, almost same as the values without $\mathrm{NH}_{3}$, indicating that the presence of $\mathrm{NH}_{3}$ had no influence on the $\mathrm{O}: \mathrm{C}$ and $\mathrm{H}: \mathrm{C}$ ratios of $\mathrm{SOA}$ from $\mathrm{LDGV}$ exhaust. An average carbon oxidation state $\left(\mathrm{OS}_{\mathrm{c}}\right)$ can be estimated from the $\mathrm{O}: \mathrm{C}$ and $\mathrm{H}: \mathrm{C}$ data [61]. The average $\mathrm{OS}_{\mathrm{c}}$ of SOA formed from LDGV exhaust with and without $\mathrm{NH}_{3}$ was 0.013 and 0.016 , respectively, which are within or near the range of semivolatile oxygenated OA (SV-OOA) $(-0.5-0)$ [61] and are consistent with the observation of Nordin et al. [26]. The presence of $\mathrm{NH}_{3}$ had no impact on the average $\mathrm{OS}_{\mathrm{c}}$ of SOA from LDGV exhaust.

\section{3 $\mathrm{NH}_{3}$ with aged gasoline vehicle exhaust}

With tremendous nitrogen fertilizer applications and animal feeding, in 2000 China contributed more than $55 \%$ of the

Table 3 Oxygen to carbon (O:C) ratio, hydrogen to carbon (H:C) ratio, and average carbon oxidation state $\left(\mathrm{OS}_{\mathrm{c}}\right)$ in experiments II-3 and II-4

\begin{tabular}{cccc}
\hline & O:C & H:C & OS $_{\mathrm{c}}$ \\
\hline II-3 & $0.684 \pm 0.042$ & $1.352 \pm 0.041$ & 0.016 \\
II-4 & $0.683 \pm 0.042$ & $1.353 \pm 0.042$ & 0.013 \\
\hline
\end{tabular}

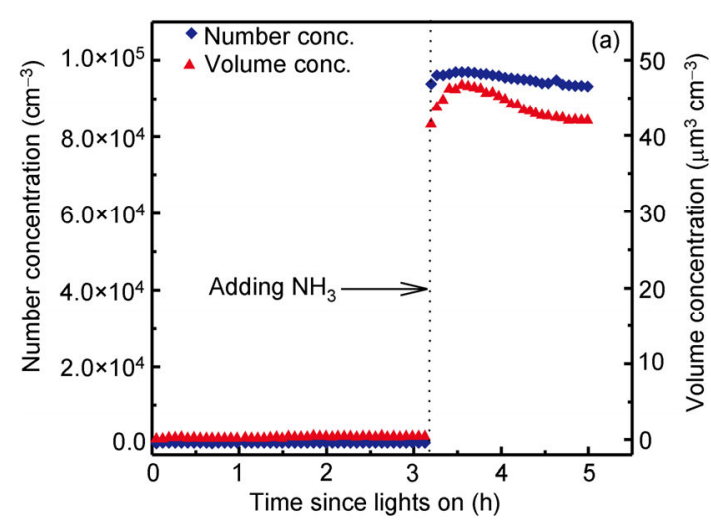

$\mathrm{NH}_{3}$ emissions in Asia [62]; in 2006, livestock waste and fertilizer in rural areas accounted for more than $85 \%$ of China's $\mathrm{NH}_{3}$ emissions [63]. Obviously, mixing of $\mathrm{NH}_{3}$ with aged GVE transported from urban areas is of concern for the air quality in rural areas. In the present study we added about $100 \mathrm{ppb}$ of $\mathrm{NH}_{3}$ into the reactor after $4 \mathrm{~h}$ (experiments I-2) and $3 \mathrm{~h}$ of irradiation (experiment II-2) to investigate the aerosol formation from aged GVE mixed with $\mathrm{NH}_{3}$. Due to the unavailability of AMS data, herein we discuss only the influence of added $\mathrm{NH}_{3}$ on the number and volume concentrations of particles. When $\mathrm{NH}_{3}$ was added, the number and volume concentrations jumped immediately to higher levels (Figure 5). For experiment II-2, the number and volume concentrations of particles increased extremely fast to about $1 \times 10^{5} \mathrm{~cm}^{-3}$ and $40 \mu \mathrm{m} \mathrm{cm}^{-3}$, respectively (Figure 5(a)). The addition of high concentrations of $\mathrm{NH}_{3}$ might stabilize sulfuric acid clusters to overcome the nucleation barrier and thereby induce the burst particle formation [49]. If so, this would indicate that the numbers and mass of particles might be greatly enhanced when aged GVE is transported to rural areas and mixed with the substantial amounts of $\mathrm{NH}_{3}$ emitted from livestock wastes and fertilizers. Reducing $\mathrm{NH}_{3}$ emissions in the agricultural sector would therefore help lower both the number and mass contribu-

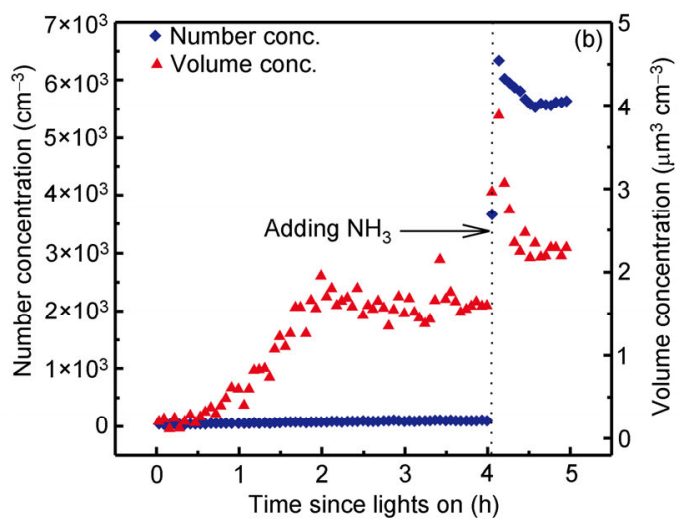

Figure 5 Effects of $\mathrm{NH}_{3}$ on the formation of particles from aging LDGV exhaust in (a) II-2 and (b) I-2. 
tions of fine particles in suburban and rural areas.

\section{Conclusions}

Smog chamber simulations about the formation of secondary aerosols from GVE with and without $\mathrm{NH}_{3}$ absorbed by denuders revealed that the presence of $\mathrm{NH}_{3}$ in GVE could enhance the formation and growth of particles. This indicates that control of $\mathrm{NH}_{3}$ emissions in urban areas, as well as control of $\mathrm{NH}_{3}$ in GVE, would suppress particle formation and growth during the early atmospheric evolution of GVE. Chamber simulations also revealed that particle numbers and mass concentrations increased rapidly to much higher levels when aged GVE was mixed with $\mathrm{NH}_{3}$, suggesting that $\mathrm{NH}_{3}$ from livestock waste and fertilizer applications would promote particle formation and growth when aged urban plumes reach rural areas. The present study therefore indicates $\mathrm{NH}_{3}$ plays vital roles in particle growth and formation in both urban and rural areas. We also found that $\mathrm{NH}_{3}$ had no significant effects on SOA formation from GVE or on the oxidation state of SOA.

This study was supported by the Strategic Priority Research Program of the Chinese Academy of Sciences (XDB05010200), the National Natural Science Foundation of China (41025012/41121063), NSFC-Guangdong Joint Funds (U0833003), and the Guangzhou Institute of Geochemistry (GIGCAS 135 Project Y234161001).

1 Seinfeld J, Pandis SN. From Air Pollution to Climate Change, Atmospheric Chemistry and Physics. 2nd ed. New York: John Wiley \& Sons, 1998. 74-75

2 Bouwman AF, Lee DS, Asman WAH, Dentener FJ, Van Der Hoek KW, Olivier JGJ. A global high-resolution emission inventory for ammonia. Glob Biogeochem Cycle, 1997, 11: 561-587

3 Asman WAH. Factors influencing local dry deposition of gases with special reference to ammonia. Atmos Environ, 1998, 32: 415-421

4 Pinder RW, Adams PJ, Pandis SN. Ammonia emission controls as a cost-effective strategy for reducing atmospheric particulate matter in the eastern united states. Environ Sci Technol, 2007, 41: 380-386

5 Chow JC, Watson JG, Fujita EM, Lu Z, Lawson DR, Ashbaugh LL. Temporal and spatial variations of $\mathrm{PM}_{2.5}$ and $\mathrm{PM}_{10}$ aerosol in the southern California air quality study. Atmos Environ, 1994, 28: 20612080

6 Chan CK, Yao X. Air pollution in mega cities in China. Atmos Environ, 2008, 42: 1-42

7 Zhang Q, He K, Huo H. Policy: cleaning China's air. Nature, 2012, 484: 161-162

8 He K, Yang F, Ma Y, Zhang Q, Yao X, Chan CK, Cadle S, Chan T, Mulawa P. The characteristics of $\mathrm{PM}_{2.5}$ in Beijing, China. Atmos Environ, 2001, 35: 4959-4970

9 Pathak RK, Wu WS, Wang T. Summertime $\mathrm{PM}_{2.5}$ ionic species in four major cities of China: nitrate formation in an ammonia-deficient atmosphere. Atmos Chem Phys, 2009, 9: 1711-1722

10 Yang F, Tan J, Zhao Q, Du Z, He K, Ma Y, Duan F, Chen G, Zhao Q. Characteristics of $\mathrm{PM}_{2.5}$ speciation in representative megacities and across China. Atmos Chem Phys, 2011, 11: 5207-5219

11 Wang XM, Ding X, Fu XX, He QF, Wang SY, Bernard F, Zhao XY, $\mathrm{Wu}$ D. Aerosol scattering coefficients and major chemical compositions of fine particles observed at a rural site hit the central Pearl River Delta, South China. J Environ Sci-China, 2012, 24: 72-77

12 Fu XX, Wang XM, Guo H, Cheung K, Ding X, Zhao XY, He QF, Gao B, Zhang Z, Liu TY, Zhang YL. Trends of ambient fine particles and major chemical components in the Pearl River Delta region: observation at a regional background site in fall and winter. Sci Total Environ, 2014, 497-498: 274-281

13 Ortega IK, Kurtén T, Vehkamäki H, Kulmala M. The role of ammonia in sulfuric acid ion induced nucleation. Atmos Chem Phys, 2008, 8: 2859-2867

14 Kirkby J, Curtius J, Almeida J, Dunne E, Duplissy J, Ehrhart S, Franchin A, Gagné S, Ickes L, Kürten A, Kupc A, Metzger A, Riccobono F, Rondo L, Schobesberger S, Tsagkogeorgas G, Wimmer D, Amorim A, Bianchi F, Breitenlechner M, David A, Dommen J, Downard A, Ehn M, Flagan RC. Role of sulphuric acid, ammonia and galactic cosmic rays in atmospheric aerosol nucleation. Nature, 2011, 476: 429-433

15 Na K, Song C, Switzer C, Cocker DR. Effect of ammonia on secondary organic aerosol formation from $\alpha$-pinene ozonolysis in dry and humid conditions. Environ Sci Technol, 2007, 41: 6096-6102

16 Huang Y, Lee SC, Ho KF, Ho SSH, Cao NY, Cheng Y, Gao Y. Effect of ammonia on ozone-initiated formation of indoor secondary products with emissions from cleaning products. Atmos Environ, 2012, 59: 224-231

$17 \mathrm{Na} \mathrm{K}$, Song C, Cocker Iii DR. Formation of secondary organic aerosol from the reaction of styrene with ozone in the presence and absence of ammonia and water. Atmos Environ, 2006, 40: 1889-1900

18 Gordon TD, Presto AA, May AA, Nguyen NT, Lipsky EM, Donahue NM, Gutierrez A, Zhang M, Maddox C, Rieger P, Chattopadhyay S, Maldonado H, Maricq MM, Robinson AL. Secondary organic aerosol formation exceeds primary particulate matter emissions for light-duty gasoline vehicles. Atmos Chem Phys, 2014, 14: 4661-4678

19 Zhang Q, Jimenez JL, Canagaratna MR, Allan JD, Coe H, Ulbrich I, Alfarra MR, Takami A, Middlebrook AM, Sun YL, Dzepina K, Dunlea E, Docherty K, DeCarlo PF, Salcedo D, Onasch T, Jayne JT, Miyoshi T, Shimono A, Hatakeyama S, Takegawa N, Kondo Y, Schneider J, Drewnick F, Borrmann S, Weimer S, Demerjian K, Williams P, Bower K, Bahreini R, Cottrell L, Griffin RJ, Rautiainen J, Sun JR, Zhang YM, Worsnop DR. Ubiquity and dominance of oxygenated species in organic aerosols in anthropogenically-influenced Northern Hemisphere midlatitudes. Geophys Res Lett, 2007, 34: L13801

20 Heald CL, Jacob DJ, Park RJ, Russell LM, Huebert BJ, Seinfeld JH, Liao H, Weber RJ. A large organic aerosol source in the free troposphere missing from current models. Geophys Res Lett, 2005, 32: L18809

21 Fraser MP, Cass GR. Detection of excess ammonia emissions from in-use vehicles and the implications for fine particle control. Environ Sci Technol, 1998, 32: 1053-1057

22 Durbin TD, Wilson RD, Norbeck JM, Miller JW, Huai T, Rhee SH. Estimates of the emission rates of ammonia from light-duty vehicles using standard chassis dynamometer test cycles. Atmos Environ, 2002, 36: 1475-1482

23 Burgard DA, Bishop GA, Stedman DH. Remote sensing of ammonia and sulfur dioxide from on-road light duty vehicles. Environ Sci Technol, 2006, 40: 7018-7022

24 Kean AJ, Littlejohn D, Ban-Weiss GA, Harley RA, Kirchstetter TW, Lunden MM. Trends in on-road vehicle emissions of ammonia. Atmos Environ, 2009, 43: 1565-1570

25 Liu TY, Wang XM, Wang BG, Ding X, Deng W, LV SJ, Zhang YL. Emission factor of ammonia $\left(\mathrm{NH}_{3}\right)$ from on-road vehicles in china: tunnel tests in urban Guangzhou. Environ Res Lett, 2014, 9: 064027

26 Nordin EZ, Eriksson AC, Roldin P, Nilsson PT, Carlsson JE, Kajos MK, Hellen H, Wittbom C, Rissler J, Londahl J, Swietlicki E, Svenningsson B, Bohgard M, Kulmala M, Hallquist M, Pagels JH. Secondary organic aerosol formation from idling gasoline passenger vehicle emissions investigated in a smog chamber. Atmos Chem Phys, 2013, 13: 6101-6116

27 Platt SM, El Haddad I, Zardini AA, Clairotte M, Astorga C, Wolf R, Slowik JG, Temime-Roussel B, Marchand N, Jezek I, Drinovec L, Mocnik G, Mohler O, Richter R, Barmet P, Bianchi F, Baltensperger $\mathrm{U}$, Prevot ASH. Secondary organic aerosol formation from gasoline vehicle emissions in a new mobile environmental reaction chamber. Atmos Chem Phys, 2013, 13: 9141-9158

28 Zhang Y, Wang X, Zhang Z, LV S, Shao M, Lee FSC, Yu JZ. Species profiles and normalized reactivity of volatile organic compounds 
from gasoline evaporation in China. Atmos Environ, 2013, 79: 110118

29 Wang X, Liu T, Bernard F, Ding X, Wen S, Zhang Y, Zhang Z, He Q, Lv S, Chen J, Saunders S, Yu J. Design and characterization of a smog chamber for studying gas-phase chemical mechanisms and aerosol formation. Atmos Meas Tech, 2014, 7: 301-313

30 Perrino C, Gherardi M. Optimization of the coating layer for the measurement of ammonia by diffusion denuders. Atmos Environ, 1999, 33: 4579-4587

31 Clairotte M, Adam TW, Zardini AA, Manfredi U, Martini G, Krasenbrink A, Vicet A, Tournié E, Astorga C. Effects of low temperature on the cold start gaseous emissions from light duty vehicles fuelled by ethanol-blended gasoline. Appl Energ, 2013, 102: 44-54

32 Zhang Y, Wang X, Blake DR, Li LF, Zhang Z, Wang SY, Guo H, Lee FSC, Gao B, Chan L, Wu D, Rowland FS. Aromatic hydrocarbons as ozone precursors before and after outbreak of the 2008 financial crisis in the Pearl River Delta region, South China. J Geophys Res, 2012, 117: D15306

33 Yi Z, Wang X, Sheng G, Zhang D, Zhou G, Fu J. Soil uptake of carbonyl sulfide in subtropical forests with different successional stages in South China. J Geophys Res, 2007, 112: D08302

34 Wang $\mathrm{X}, \mathrm{Wu} \mathrm{T}$. Release of isoprene and monoterpenes during the aerobic decomposition of orange wastes from laboratory incubation experiments. Environ Sci Technol, 2008, 42: 3265-3270

35 Zhang YL, Guo H, Wang XM, Simpson I, Barletta B, Blaked DR, Meinardi S. Emission patterns and spatiotemporal variations of halocarbons in the Pearl River Delta region, southern China. J Geophys Res, 2010, 115: D15309

36 Lindinger W, Hansel A, Jordan A. On-line monitoring of volatile organic compounds at pptv levels by means of proton-transfer-reaction mass spectrometry (PTR-MS) medical applications, food control and environmental research. Int J Mass Spectrom Ion Process, 1998, 173: 191-241

37 Jordan A, Haidacher S, Hanel G, Hartungen E, Märk L, Seehauser H, Schottkowsky R, Sulzer P, Märk TD. A high resolution and high sensitivity proton-transfer-reaction time-of-flight mass spectrometer (PTR-TOF-MS). Int J Mass Spectrom, 2009, 286: 122-128

38 Zhang Q, Worsnop DR, Canagaratna MR, Jimenez JL. Hydrocarbonlike and oxygenated organic aerosols in Pittsburgh: insights into sources and processes of organic aerosols. Atmos Chem Phys, 2005, 5: 3289-3311

39 Jayne JT, Leard DC, Zhang X, Davidovits P, Smith KA, Kolb CE, Worsnop DR. Development of an aerosol mass spectrometer for size and composition analysis of submicron particles. Aerosol Sci Tech, 2000, 33: 49-70

40 DeCarlo PF, Kimmel JR, Trimborn A, Northway MJ, Jayne JT, Aiken AC, Gonin M, Fuhrer K, Horvath T, Docherty KS, Worsnop DR, Jimenez JL. Field-deployable, high-resolution, time-of-flight aerosol mass spectrometer. Anal Chem, 2006, 78: 8281-8289

41 Aiken AC, DeCarlo PF, Jimenez JL. Elemental analysis of organic species with electron ionization high-resolution mass spectrometry. Anal Chem, 2007, 79: 8350-8358

42 Aiken AC, DeCarlo PF, Kroll JH, Worsnop DR, Alex Huffman J, Docherty KS, Ulbrich IM, Mohr C, Kimmel JR, Sueper D, Sun Y, Zhang Q, Trimborn A, Northway M, Ziemann PJ, Canagaratna MR, Onasch TB, Rami Alfarra M, Prevot ASH, Dommen J, Duplissy J, Metzger A, Baltensperger U, Jimenez JL. O/C and OM/OC ratios of primary, secondary, and ambient organic aerosols with high-resolution time-of-flight aerosol mass spectrometry. Environ Sci Technol, 2008, 42: 4478-4485

43 McMurry PH, Grosjean D. Gas and aerosol wall losses in teflon film smog chambers. Environ Sci Technol, 1985, 19: 1176-1182

44 Pathak RK, Stanier CO, Donahue NM, Pandis SN. Ozonolysis of alpha- pinene at atmospherically relevant concentrations: temperature dependence of aerosol mass fractions (yields). J Geophys Res-Atmos, 2007, doi: 10.1029/2006JD007436

45 Hurley MD, Sokolov O, Wallington TJ, Takekawa H, Karasawa M, Klotz B, Barnes L, Becker KH. Organic aerosol formation during the atmospheric degradation of toluene. Environ Sci Technol, 2001, 35: 1358-1366

46 Johnson D, Jenkin ME, Wirtz K, Martin-Reviejo M. Simulating the formation of secondary organic aerosol from the photo-oxidation of toluene. Environ Chem, 2004, 1: 150-165

47 Wildt J, Mentel TF, Kiendler-Scharr A, Hoffmann T, Andres S, Ehn M, Kleist E, Müsgen P, Rohrer F, Rudich Y, Springer M, Tillmann R, Wahner A. Suppression of new particle formation from monoterpene oxidation by $\mathrm{NO}_{x}$. Atmos Chem Phys, 2014, 14: 2789-2804

$48 \mathrm{Ng}$ NL, Kroll JH, Chan AWH, Chhabra PS, Flagan RC, Seinfeld JH. Secondary organic aerosol formation from $m$-xylene, toluene, and benzene. Atmos Chem Phys, 2007, 7: 3909-3922

49 Kulmala M, Kontkanen J, Junninen H, Lehtipalo K, Manninen HE, Nieminen T, Petäjä T, Sipilä M, Schobesberger S, Rantala P, Franchin A, Jokinen T, Järvinen E, Äijälä M, Kangasluoma J, Hakala J, Aalto PP, Paasonen P, Mikkilä J, Vanhanen J, Aalto J, Hakola H, Makkonen U, Ruuskanen T, Mauldin RL, Duplissy J, Vehkamäki H, Bäck J, Kortelainen A, Riipinen I, Kurtén T, Johnston MV, Smith JN, Ehn M, Mentel TF, Lehtinen KEJ, Laaksonen A, Kerminen VM, Worsnop DR. Direct observations of atmospheric aerosol nucleation. Science, 2013, 339: 943-946

50 Mönkkönen P, Koponen IK, Lehtinen KEJ, Hämeri K, Uma R, Kulmala M. Measurements in a highly polluted Asian mega city: observations of aerosol number size distribution, modal parameters and nucleation events. Atmos Chem Phys, 2005, 5: 57-66

51 Setyan A, Song C, Merkel M, Knighton WB, Onasch TB, Canagaratna MR, Worsnop DR, Wiedensohler A, Shilling JE, Zhang Q. Chemistry of new particle growth in mixed urban and biogenic emissions-insights from cares. Atmos Chem Phys, 2014, 14: 6477-6494

52 Zhu Y, Sabaliauskas K, Liu X, Meng H, Gao H, Jeong CH, Evans GJ, Yao X. Comparative analysis of new particle formation events in less and severely polluted urban atmosphere. Atmos Environ, 2014, 98: 655-664

53 Dusek U, Frank GP, Hildebrandt L, Curtius J, Schneider J, Walter S, Chand D, Drewnick F, Hings S, Jung D, Borrmann S, Andreae MO. Size matters more than chemistry for cloud-nucleating ability of aerosol particles. Science, 2006, 312: 1375-1378

54 Petters MD, Kreidenweis SM. A single parameter representation of hygroscopic growth and cloud condensation nucleus activity. Atmos Chem Phys, 2007, 7: 1961-1971

55 Tkacik DS, Lambe A, Jathar S, Li X, Presto AA, Zhao Y, Blake D, Meinardi S, Jayne JT, Croteau PL, Robinson AL. Secondary organic aerosol formation from in-use motor vehicle emissions using a potential aerosol mass reactor. Environ Sci Technol, 2014, 48: 1123511242

56 Zhang Q, Stanier CO, Canagaratna MR, Jayne JT, Worsnop DR, Pandis SN, Jimenez JL. Insights into the chemistry of new particle formation and growth events in Pittsburgh based on aerosol mass spectrometry. Environ Sci Technol, 2004, 38: 4797-4809

57 Crilley LR, Jayaratne ER, Ayoko GA, Miljevic B, Ristovski Z, Morawska L. Observations on the formation, growth and chemical composition of aerosols in an urban environment. Environ Sci Technol, 2014, 48: 6588-6596

58 Zhang YM, Zhang XY, Sun JY, Lin WL, Gong SL, Shen XJ, Yang S. Characterization of new particle and secondary aerosol formation during summertime in Beijing, China. Tellus B, 2011, 63: 382

59 Pankow JF. An absorption-model of gas-particle partitioning of organic-compounds in the atmosphere. Atmos Environ, 1994, 28: $185-188$

60 Updyke KM, Nguyen TB, Nizkorodov SA. Formation of brown carbon via reactions of ammonia with secondary organic aerosols from biogenic and anthropogenic precursors. Atmos Environ, 2012, 63 : 22-31

61 Kroll JH, Donahue NM, Jimenez JL, Kessler SH, Canagaratna MR, Wilson KR, Altieri KE, Mazzoleni LR, Wozniak AS, Bluhm H, Mysak ER, Smith JD, Kolb CE, Worsnop DR. Carbon oxidation state as a metric for describing the chemistry of atmospheric organic aerosol. Nat Chem, 2011, 3: 133-139

62 Streets DG, Bond TC, Carmichael GR, Fernandes SD, Fu Q, He D, Klimont Z, Nelson SM, Tsai NY, Wang MQ, Woo JH, Yarber KF. An inventory of gaseous and primary aerosol emissions in Asia in the year 2000. J Geophys Res, 2003, 108: 8809

63 Huang X, Song Y, Li M, Huo Q, Cai X, Zhu T, Hu M, Zhang HS. A high-resolution ammonia emission inventory in China. Glob Biogeochem Cycle, 2012, doi: 1010.1029/2011GB004161 